coral bed, but was of inconsiderable thickness. The third was found among the uppermost Ragstones capping Cleeve, Leckhampton, Painswick, Stinchcombe, and Dursley hills. In the Great Oolite there was a coral-bed about the horizon of the Forest Marble, near Fairford ; the Oxford Clay was without such structures, but in the Coral Rag and Coralline Oolite, coral-beds were again found. Steeple Ashton, in Wiltshire, had been long famous for its coral-banks, and in the Coralline Oolite, near Scarborough, there was a very considerable development of a coral-bed, some of the best road material in that region being obtained from the crystalline limestone raised out of the old coral-bank of the Oolitic sea. The Kimmeridge Clay, like the Oxford Clay, was devoid of coralline structures, but in the Portland Oolite another coral-bank was found at Tisbury, in Wiltshire. One fact worthy of note is this, that the species of corals found in all these different beds are quite distinct speeifically from each other, every period of time having had different forms of architects in building these structures in the ancient seas, and all of them generically distinct from those which exist at the present period. The great lapse of time which our present modern reefs and islands represented was next pointed out, for it could easily be demonstrated that as the coral-polypes raise their structure very slowly, a long period of time was required to build up a structure like the barrier reef of Australia, which represented a wall of coral rock that would extend over 1250 statute miles in length by from 10 to 90 miles in width. The calculations that had been made of the age of these modern structures showed that many thousands of years were requisite for the work which had been performed by the existing races of the coral polype.

Dr. Wright's address was followed by a paper on the Geology of Canada, by a member of the Malvern Club, Captain Serocold, whose discourse, illustrated by a well-drawn map, treated with great ability the general features of the country, with their "Laurentian," "Potsdam," and "Trenton" beds, in many respects so different from anything in this country, yet presenting in their contained organisms features of analogy which have enabled geologists to correlate them with our own more familiar geological areas, so that they have been found mutually to illustrate each other.

With this paper the proceedings were brought to a close, and the party broke up, after a day of great enjoyment.

Great credit is due to the Honorary Secretary, Dr. Paine, of Stroud, for the excellence and punctuality in the arrangements.-T.W.

\title{
COREISPONDEINCE.
}

\section{DISCOVERY OF WULFENITE, ETC., IN PEMBROKESHIRE.}

To the Editor of the Geological Magazine.

Drar SIR,--It may be interesting to some of your readers to know that I have lately discovered, in Pembrokeshire, small, but 
well-formed, tabular crystals of Wulfenite (Molybdate of Lead), at the Treffgarn Rocks, between Haverfordwest and Fishguard. They occur in small cavities, which are irregularly dispersed through the rock (a felstone according to the geological map of the district), are of a brown or honey-yellow colour, semi-transparent, with the edges bevelled, and in form answer to fig. 5 in Phillips" "Mineralogy" (4th edition). I also obtained a substance of a greenish-grey colour, disseminated in small veins and patches, which is probably the same mineral in a massive form. Minute but exceedingly perfect crystals of tin likewise occur, similarly to those of the Wulfenite; but, as far as I have been able to observe, in a separate portion of the rock.

I may as well mention that I have recently found some fine black crystals of Blende (sulphide of zinc) at the tunnel near the Patchway Station on the Bristol and South Wales Union Railway. I am not aware that this mineral has been met with before in Gloucestershire, or the neighbouring counties.-I remain, dear Sir, yours very truly,

Spencer George Puroevar.

Severn House, Hexburt, Bristor, June 11th, 1866.

THE REV. T. G. BONNEY ON "TRACES OF GLACIERS IN THE ENGLISH LAKES."

To the Editor of the Grological Magazine.

Drar SrR,-In reference to the paper by the Rev. T. G. Bonney on "Traces of Glaciers in the English Lakes" in the July number of the Grologicas Magazine, the author will find that the subject has already been diseussed to some extent by Mr. R. Chambers, and more recently by myself in a paper, with illustrations, "On the Glacial Vestiges of the Lake District," published in Vol. xi. of the "Edinburgh New Philosophical Journal," (1860), and that the remarkable ice-worn rock on the north side of St. Mary's Churchyard, Ambleside, is figured both in that paper and subsequently in Lyell's "Antiquity of Man," p. 269. The Glacial phenomena of Wastdale (or Wast-water), not the "Wastdale" of Professor Phillips' Memoir, are also described in one of the last numbers of your Magazine's predecsssor-" "The Geologist;" and the whole subject, with its relations to the glacial phenomena of North Wales, as worked ont by Professor Ramsay, is touched upon in a recent number of the "Memoirs of the Literary and Philosophical Society of Manchester" (1864). The exact reference to which, absence from home prevents me from giving. I hope Mr. Bonney will not suppose that, in sending this information, I wish to underrate whatever is new and interesting in his paper, which is far from my intention.

I remain, very truly, yours,

Dodguas, Isls of Man, 9th July, 1866.

Edward HuLL. 